\title{
Lumen
}

Selected Proceedings from the Canadian Society for Eighteenth-Century Studies

\section{Point of View and Narrative Form in Moll Flanders and the Eighteenth-Century Secret History}

\section{Noelle Gallagher}

Volume 25, 2006

URI : https://id.erudit.org/iderudit/1012083ar

DOI : https://doi.org/10.7202/1012083ar

Aller au sommaire du numéro

Éditeur(s)

Canadian Society for Eighteenth-Century Studies / Société canadienne d'étude du dix-huitième siècle

ISSN

1209-3696 (imprimé)

1927-8284 (numérique)

Découvrir la revue

Citer cet article

Gallagher, N. (2006). Point of View and Narrative Form in Moll Flanders and the Eighteenth-Century Secret History. Lumen, 25, 145-161.

https://doi.org/10.7202/1012083ar

Copyright (c) Canadian Society for Eighteenth-Century Studies / Sociéte canadienne d'étude du dix-huitième siècle, 2006
Ce document est protégé par la loi sur le droit d'auteur. L'utilisation des services d'Érudit (y compris la reproduction) est assujettie à sa politique d'utilisation que vous pouvez consulter en ligne.

https://apropos.erudit.org/fr/usagers/politique-dutilisation/ 


\section{Point of View and Narrative Form in Moll Flanders and the Eighteenth-Century Secret History}

In a recent essay on the origins of the eighteenth-century novel entitled 'The Rise of I,' Philip Stewart argues that 'what really revolutionized the novel's forms and fortunes everywhere was the realization of the advantages of first-person narrative. ${ }^{1}$ A work like Moll Flanders, cited among Stewart's examples, owes not just its contemporary popularity, in fact, but also its subsequent canonization, in part to the use of first-person narration. For critics working in the immediate wake of Ian Watt's Rise of the Novel, narrative voice was one of the main features used to defend the status of Defoe's novels - often written in haste and published out of economic necessity - as 'literature.' The 'conscious artistry' of Defoe's Moll Flanders, according to critics like Robert R. Columbus, lay chiefly in the consideration that its author never compromised 'the point of view of a limited mind. ${ }^{2}$

From a generic perspective and a disciplinary one, much still hinges on the notion that Moll Flanders is written 'in the first person.' Yet on examining the novel, it is immediately apparent that the text's chief agent is not actually its narrator. The novel's preface, a first-person account by an editor figure who has rendered 'the original of this Story ... into new Words,' reveals that there is, as Larry Langford observes, 'a second voice at work in the text, separate from that of Moll, yet so deeply intertwined

* I am grateful to James Chandler, Nathan Wolff, R. P. Gallagher, and Mark Phillips for their help with this paper.

1 Philip Stewart, 'The Rise of I,' Eighteenth-Century Fiction 13 (2001), 174.

2 Robert R. Columbus, 'Conscious Artistry in Moll Flanders,' Studies in English Literature 3 (1963): 415-32. For Watt's account of Moll Flanders, see The Rise of the Novel: Studies in Defoe, Richardson and Fielding (Berkeley: University of California Press, 1957), 93-134. 
with her own that the two are difficult to distinguish. ${ }^{3}$ That preface concludes, moreover, with the editor's explanation that he has taken the final portion of the narrative not from Moll's own memorandums, but from 'her Husband's Life .. . written by a third Hand. ${ }^{4}$ Moll's account itself casts doubts on the consistency of the text's narrative voice, as Moll not only contradicts herself, but also frequently incorporates large portions of narrative that have been relayed to her by other, often unknown or unacknowledged, sources. ${ }^{5}$ She includes several lengthy accounts of conversations among the Colchester family, for example, for which neither she nor the eldest son who is presumably reporting them to her were present. ${ }^{6}$ Likewise, she constructs much of the narrative of her own early life from an undistinguished mixture of what she 'can Recollect' and what she 'could ever learn of [her]self' from reports.'

Apparently, then, the 'conscious artistry' of Moll Flanders lies less in Defoe's refusal to compromise a limited point of view than in his ability to maintain the illusion of a consistent narrative voice. Part of what makes that illusion successful, I wish to suggest here, is Defoe's rhetorical juxtaposition of the novel's first-person memoir against an imagined third-person account of Moll's life - a strategy also prevalent in the early modern secret history. In the pages that follow, I will attempt to sketch some of the rhetorical similarities between the use of point of view in

3 Daniel Defoe, The Fortunes and Misfortunes of the Famous Moll Flanders, ed. David Blewett (London: Penguin, 1989), 37 [hereafter abbreviated MF]; Larry L. Langford, 'Retelling Moll's Story: The Editor's Preface to Moll Flanders,' The Journal of Narrative Technique 22 (1992): 164. Henry N. Rogers III also sees two voices in Moll: that of the older Moll who writes the text, and that of the young Moll who acts in it. See Rogers, 'The Two Faces of Moll,' The Journal of Narrative Technique 9 (1979), 117-25.

$4 \mathrm{MF}, 47$.

5 Almost every major study of the novel addresses the question of Moll's reliability as a narrator. Much of this critical discussion is framed as a debate over the novel's 'irony,' or 'confusion of distance,' as Wayne Booth terms it, between implied author and agent-narrator. See Booth, The Rhetoric of Fiction (Chicago: University of Chicago Press, 1983), 320-24. The best-known ironic readings of the text are Dorothy van Ghent, 'On Moll Flanders' in Essays on the Eighteenth-Century Novel, ed. Robert Donald Spector (Bloomington: Indiana University Press, 1965), 3-4; Alan Dugald McKillop, Early Masters of English Fiction (Lawrence: University of Kansas Press, 1956), 31-33; and Maximillian E. Novak, 'Defoe's Use of Irony' in Novak and Herbert J. Davis, Irony in Defoe and Swift (Los Angeles: William Andrews Clark Memorial Library, 1966), 7-38. The best-known unironic reading is Ian Watt's.

6 See, for example, MF, 88-89.

$7 \mathrm{MF}, 45$. 
Moll Flanders and the use of point of view in the secret history. Using Defoe's The Secret History of the White-Staff (1714-15) as my primary example, I will demonstrate how both texts present themselves as private-sourced correctives to a more public account of the past, using the apparent disjunction between different points of view in order to establish their narrative authority.

\section{The Secret History and Problems of Narrative Voice}

Like the formal history and the memoir, the early-eighteenth-century secret history had a Classical progenitor. ${ }^{8}$ Procopius's Anekdota, first translated in 1674 as The Secret History of the Court of the Emperor Justinian, was written largely as a corrective to Procopius's own earlier works, the state-sanctioned History in Eight Books and Edifices. As a Greek historian writing during dangerous Byzantine times, Procopius produced the propagandistic History and Edifices as a means of insinuating himself into Justinian's good graces. The tactic had been successful: despite his secret loathing for the emperor and his court, Procopius was made a senator. After Justinian's death, however, Procopius composed the Anekdota (the original Attic title means 'unpublishable'), a ruthless, scandal-stuffed exposé devoted to revealing all the details of court life that the official texts had been obliged to suppress. The work was unabashedly partisan, featuring chapters detailing 'how Theodora, most depraved of all cour-

8 The most recent discussion of the secret history form can be found in Michael McKeon, The Secret History of Domesticity: Public, Private, and the Division of Knowledge (Baltimore: Johns Hopkins University Press, 2005), 469-73. While I have retained much of the language of 'public' and 'private' contained in my original presentation of this paper in October of 2004, readers will find a far more extensive account of the secret history as it relates to the emerging split between public and private in this new book. For other accounts of the form, see Lionel Gossman, 'Anecdote and History,' History and Theory 42 (2003), 151-55; John J. Richetti, Popular Fiction Before Richardson: Narrative Patterns 1700-1739 (Oxford: Clarendon, 1969), 119-67; Robert Mayer, History and the Early English Novel: Matters of Fact from Bacon to Defoe (Cambridge: Cambridge University Press, 1997), 94-112; Annabel Patterson, 'Marvell and Secret History' in Marvell and Liberty, ed. Warren Chernaik and Martin Dzelzeinis (Houndmills: MacMillan Press, 1999), 27-29; and Michael McKeon, The Origins of the English Novel (Baltimore: Johns Hopkins University Press, 1987), 54-55. For more general discussions of the use of Classical models in early modern historical practice, see Philip Hicks, Neoclassical History and English Culture from Clarendon to Hume (Houndmills: MacMillan, 1996); Joseph Levine, The Battle of the Books: History and Literature in the Augustan Age (Ithaca: Cornell University Press, 1991). 
tesans, won Justinian's love,' and 'proving that Justinian and Theodora were actually fiends in human form.' Based on Procopius's own experiences, combined with information from other 'inside' sources, The Secret History was both personal memoir and unauthorized biography, a form of historical narrative in which the teller was not always the primary agent in the events, but often the primary witness of them. The 1674 English translation was composed as a first-person narrative.

Secret histories became immensely popular, both in England and in France, in the late seventeenth and eighteenth centuries. (Procopius's text appeared in French translation in 1669, and the form caught on there before it did in England). Like the more general term 'history,' the label 'secret history' was applied to narratives of widely varying lengths and styles, from polemical pamphlets (John Oldmixon's Secret History of Europe [1712]) to anthologies (Sir Walter Scott's Secret History of the Court of James the First [1811]) to the scandal chronicles that have been likened by present-day literary critics to early-eighteenth-century novels (Elizabeth Delariviere Manley's Secret History of Queen Zarah [1705]). What many of these narratives had in common was an avowed intention of exposing the 'secret' truth behind misrepresented, or unrepresented, public persons and events. Like Procopius's Anekdota, these texts attempted to undermine a prevailing view of the past - typically the recent past - by presenting opposing testimony from one or more traitorous insiders. ${ }^{9}$ By emphasizing agents typically excluded from authorized accounts of historical change (women, servants, lesser public officials) and actions typically concealed from public view (intrigues, seductions, conspiracies), secret histories could issue implicit challenges to established social, political, and intellectual values, replacing a rational, causal narrative of the past with a haphazard, contingent series of episodes. Such works also could endanger their writer: since secret histories often revealed information that only could have been obtained by an insider, they frequently implicated the historian as the text's traitorous narrator. ${ }^{10}$ That authorial presence was sometimes indicated, on a formal level, by the use of first-person narration. ${ }^{11}$

9 On the importance of recentness to early modern narrative, see J. Paul Hunter, Before Novels: The Cultural Contexts of Eighteenth-Century English Fiction (New York: Norton, 1990), 167-94; Daniel Woolf, The Social Circulation of the Past: English Historical Culture 1500-1730 (Oxford: Oxford University Press, 2003). Secret histories responding to accounts of the distant past tended to challenge the conventional narrative interpretations found in formal histories, while those responding to more recent events often critiqued a general opinion derived from periodical publications. 
The Secret History of the White-Staff, one of Daniel Defoe's better-known treatments of the form, maintains the focus on private subject matter and private perspectives that was characteristic of the secret history in early modern practice. ${ }^{12}$ Written as a defense of Defoe's sometime patron, the Lord Treasurer Robert Harley, this three-part narrative attempts to reverse the prevailing public contempt for Harley (referred to metonymically as the 'White-Staff') by recasting him as a political scapegoat. The text's narrator begins, however, with a more general critique of the notion of individual historical agency, arguing that all public leaders are forced to 'bear the Guilt of other Men's Crimes,' because they cannot 'act without the Agency and Councils of such Seconds, who, as they ought to share in the Glory ... cannot be clear of the Blame. ${ }^{13}$ Citing as his historical precedents 'Cardinal Richlieu [sic] supplanting his Benefactress' and Thomas Becket's betrayal of 'the King that advanc'd him,' Defoe's narrator recasts the accepted account of Harley's crimes and dismissal as a series of elaborate conspiracies, insisting that the WhiteStaff himself had 'no secret Designs to betray the Constitution,' but that 'this Negative introduced a War between him and those who, to outward Appearance, were in the same Interest with him. ${ }^{14}$

Throughout his account of the White-Staff's time in office, Defoe's narrator contrasts the negative public opinion of Harley's ministry with the hidden truth of the Lord Treasurer's honourable designs, constructing a laudatory corrective biography of Harley on the basis of the latter's

10 The sense of writer-as-traitor is nicely invoked by the many secret histories of clubs and secret societies that appeared during the period, typically billed as being penned 'by a Member.' See, for example, Defoe's Secret History of the October Club (1711).

11 Some secret histories used first-person narration throughout; others, particularly those that dealt with the distant past or tackled a broader historical topic, used first-person narration for embedded commentary or in the extra-textual material. See, for example, John Oldmixon's Secret History of Europe (London, 1712), a work 'collected from Authentick Memoirs' but replete with first-person commentary.

12 While all of Defoe's bibliographers include secret histories in his list of works, the precise number of such narratives attributed to him remains open to debate. See John Robert Moore, A Checklist of the Writings of Daniel Defoe (Bloomington: Indiana University Press, 1960); P. N. Furbank and W. R. Owens, A Critical Bibliography of Daniel Defoe (London: Pickering \& Chatto, 1998) for a liberal and a conservative bibliography, respectively.

13 Daniel Defoe, The Secret History of the White-Staff, Being an Account of Affairs Under the Conduct of Some Late Ministers, and of What Might Have Happened if Her Majesty Had Not Died (London: J. Baker, 1714), 1.3-4 [hereafter abbreviated WS].

14 WS, 1.5 . 
unspoken intentions and unseen acts. The text effects its vindication both by praising the Staff's own private conduct, and by blackening that of his heretofore-concealed enemies. It casts Harley as the victim of treacherous advisors, discounting the treasurer's own responsibility for his ministry's errors by foregrounding 'the Agency of those Instruments ... acting with different Views from those under whose Conduct, and by whose Authority, they were introduc'd. ${ }^{15}$ The lower public profile of these villainous conspirators (the group includes a 'cunning' noblewoman and several lower-class informers employing the 'Female Buz' of gossip, as well as lesser-known male figures) enables them to conceal their machinations, while Harley, the figure most often before the public eye, unjustly takes the blame: ${ }^{16}$ 'The White-Staff being supposed to be at the Head of all Affairs, the Odium of every false Step was sure to be laid there, the popular Hatred was certain to center there, and he was like to be charg'd with the very Mistakes, which he had openly and avowedly opposed. ${ }^{17}$ Harley's enemies succeed, the narrator asserts, because the 'artificial Calumny, which some [of them] industriously [strive] to make popular,' eventually does gain widespread acceptance as the truth. ${ }^{18}$ Unlike the plain-spoken treasurer, the conspirators are able to manipulate the public point of view.

However innocent the opening strains of The Secret History might make the White-Staff appear, the evidence surrounding Harley's public conduct cannot always be explained in such a way as to present the minister himself as wholly free of blame. Indeed, part of what makes this secret history, among Defoe's various writings in the form, a particularly interesting comparative with Moll Flanders, is its deployment of the rhetoric of eyewitness experience for defensive, rather than offensive, purposes. ${ }^{19}$ Accordingly, Defoe's narrator is sometimes openly critical of Harley for his duplicity, and sometimes excuses him on the grounds that those who were duped by his machinations deserved to be deceived.

15 Ibid.

16 WS, 1.42. Defoe's recognition that a 'secret' history reveals hidden agents as well as private events is nicely suggested by the narrator's comments on Lady Masham: 'the secret Part of this History is, that there is a Woman in the Bottom of all this Matter' (WS, 2.29).

17 WS, 1.39 .

18 WS, 2.23 .

19 See J. A. Downie, Robert Harley and the Press: Propaganda and Public Opinion in the Age of Swift and Defoe (Cambridge: Cambridge University Press, 1979), 186. 
The narrator argues that the Jacobites, for example, 'had very just Cause to resent the Conduct of the Staff, and that they were dup' $\mathrm{d}$ and bubbled ... in the grossest and most obvious Manner,' but contends that 'they had much more Reason to blame their own Credulity, than any other Cause. ${ }^{20}$ Likewise, he transforms Harley's defeat of the Schism Bill, 'a Mine dug to blow up the White-Staff,' into a showcase for the treasurer's cunning against those who are conspiring against him. 'He was so well acquainted with their Management in all its Steps, and made himself so effectually Master of the Plot, even before it broke out,' the narrator boasts, 'that he baffled them both ways. ${ }^{21}$ In these instances, the roles of deceived and deceiver begin to merge, and Defoe's narrator betrays a suspiciously pleasurable sympathy with the less honourable side of his hero's character.

That sympathetic connection did not go unnoticed by contemporary readers. Indeed, many believed that The White-Staff had been penned by Harley himself. ${ }^{22}$ Given the private nature of the information that The Secret History revealed, and the insistence with which it attempted to vindicate the treasurer, it is easy to see how the ' $\mathrm{I}$ ' of Defoe's anonymous narrator could have been attributed to the man whose interests he so clearly represented. Not only is the writer often reporting events that he himself has witnessed ('I remember very well, in a Conference between two Persons of the first Rank, this Matter was mentioned ...' $)^{23}$ but he is also clearly in contact with other insiders who share his controversial views. The White-Staff's narrator maintains his credibility in part by incorporating first-person gestures towards his sources that vouch for their reliability. In these instances, the narrator's own authority both supports, and is supported by, the presence of similar or 'stronger Evidences' from his additional informants. ${ }^{24}$

Despite its energetic efforts to manipulate public opinion, the relative truth claims of The Secret History of the White-Staff have not well withstood the test of time. The few literary critics who have commented on the text have typically critiqued Defoe's portrayal of historical persons and events as inaccurate and deceptive. Geoffrey Sill, for example, brands The White-Staff a work of 'fiction,' arguing that 'its strategy is not to See Furbank and Owens, 148. 
reproduce historical circumstances, but to transform them into ideological types, which are then presented as history. ${ }^{25}$ In writing The Secret History of the White-Staff, Sill contends, Defoe 'found the formula out of which he was to make his major fictions. ${ }^{26}$ Maximillian Novak likewise singles out The White-Staff as an important precursor to Defoe's novels, claiming that The Secret History's treatment of character and style foreshadowed the author's later literary successes: 'the "Staff," as Defoe calls Harley throughout, may . . . be said to be Defoe's first well-developed character. And since Defoe knew that every word and every innuendo would be carefully scrutinized, he wrote with a purity of style that was almost unique for a writer accustomed to rushing out copy to reflect upon each passing event. ${ }^{27}$

In both of these discussions of The White-Staff, however, an important distinction emerges between critical treatments of Defoe's novels and analyses of his 'non-fiction' writings. According to Novak, 'Defoe chose to write almost all of his fiction through first-person narrative, but he showed in this account how well he could handle third-person narrative. ${ }^{28}$ Likewise, Sill views The White-Staff's separation of protagonist and narrator as one of the few impediments to his critical argument for the work's fictionality: 'It was written as a narrative,' he asserts, 'but in the third person, while most of Defoe's major works now recognized as fictions were written in the first person. ${ }^{29}$ Yet given that The White-Staff not only presents a narrating 'I,' but aligns that first-person voice with

25 Geoffrey Sill, Defoe and the Idea of Fiction 1713-1719 (Newark: University of Delaware Press, 1983), 93.

26 Ibid.

27 Maximillian E. Novak, Daniel Defoe: Master of Fictions (Oxford: Oxford University Press, 2001), 462-63.

28 Novak, 462.

29 Sill, 88. See also E. Anthony James, Daniel Defoe's Many Voices: A Rhetorical Study of Prose Style and Literary Method (Amsterdam: Rodopi, 1972). James divides his analysis of Defoe's writings into 'three generic categories defined by authorial point of view, or focus of narration. These are (1) non-fictional works whose authorship Defoe usually acknowledged (2) short, often ironic works of mimicry purportedly written by someone other than Defoe - a righteous indigent, a High-flying Anglican, a Jacobite, etc. (3) long, purportedly-autobiographical works of fiction written from the first-person point of view of narrators like Robinson Crusoe, Moll Flanders and Roxana' (1). It is a testament to the problematic nature of James's approach that it is impossible to know where in such a schema to place a work like The White-Staff, since this narrative remained unacknowledged by Defoe, but also fails to qualify as 'short' (its three parts stretch to a length of over two hundred pages). 
the actions and opinions of the text's principal agent, surely to label The Secret History of the White-Staff as 'third person' is to elide the sophisticated ways in which the text mediates between different points of view - and thus to overlook another point of convergence between Defoe's novels and his other prose writings.

\section{Narrative Authority and The Secret History of Moll Flanders}

Returning to the questions of narrative authority that I outlined at the beginning of this paper, I wish to suggest here that one of the main reasons we are willing to collapse the many unreliable voices of Moll's narrative into a single trustworthy ' $\mathrm{I}$ ' stems from our sense that we are being granted privileged access to her secret history. Although Moll is clearly the principal agent in her own story, and not, like Defoe's narrator in The White-Staff, just an invested eyewitness of it, her narrative relies on very similar disjunctions between private motive and public action to mount its defense of its protagonist. ${ }^{30}$ From its very title page, Moll Flanders promises us the biography of a woman of whose life other public accounts apparently already exist. She is 'the famous Moll Flanders,' a figure so generally known that by the time she is finally tried at Newgate, 'so prevailing [is] the fatal Report of being an old Offender' that 'the Recorder [is] pleas'd to represent [her] Case as he [thinks] fit' despite her having 'never been before them in a judicial way before. ${ }^{31}$ What separates this account of Moll from the imaginary broadsheets, ballads, newspaper reports, and biographies that have made her famous is, of course, a matter of point of view: this history, unlike the popular reports, is 'written from her own Memorandums.'

As a privately-sourced document, Moll Flanders reveals the hidden thoughts and actions behind the public history of its protagonist's former life as a thief and a whore; the novel's main subjects - sexual intrigue and financial scheming - are therefore akin to those of many secret histories. Like The Secret History of the White-Staff, Defoe's novel consistently draws the reader's attention to an alleged contrast between private and public histories of the same persons and events. Indeed,

30 I am collapsing Moll's voice with that of her editor here, as it is impossible to determine which expressions belong to which contributor. It is perhaps worth observing, however, that if the editor of the preface is the work's 'real' narrator, then Moll Flanders presents a narrator-agent relationship even closer to that of The White-Staff.

31 MF, 371. 
Moll's witty observation after her second husband's clandestine flight into France - 'I had a Husband, and no Husband' - functions as a neat encapsulation of the disjunction between different points of view that structures the novel as a whole. ${ }^{32}$ The penitent Moll's Protestant emphasis on motives over deeds can likewise be understood as a way in which the novel dramatizes the split between interior and exterior forms of narration. ${ }^{33}$

Because Moll Flanders recounts scandalous subject matter, it is presented to the reader as a censored work, with the proper names of the 'historical' persons and places Moll encounters carefully excised. The censoring of aristocratic names in particular implicates Defoe's novel in some of the same challenges to social and political order posed by secret histories. Because so many of the individuals she robs, seduces, or swindles hold positions of power, Moll, like the narrator of The WhiteStaff, often functions as a spy on the social superiors whose world she has successfully infiltrated and exposed. ${ }^{34}$ Likewise, the novel's characters occasionally rely, as The White-Staff does, on metonymic or allegorical symbols: the governess, for example, uses a 'Sign of the Cradle' to designate her hidden residence. ${ }^{35}$ These censored passages invite the reader to participate in the shared confidence of the text's narration, aiding Moll's treacherous exposure of historical persons by inserting the requisite names and places into the blanks. Sometimes, he or she is even requested to contribute whole episodes:

He spoke this in so much more moving Terms than it is possible for me to Express, and with so much greater force of Argument than I can repeat, that I only recommend it to those who Read the Story, to suppose, that as he held me above an Hour and Half in that Discourse, so he answer'd all my Objections, and fortified his Discourse with all the Arguments, that human Wit and Art could Devise. $^{36}$

$32 \mathrm{MF}, 108$.

33 See, for example, MF, 102, 187, 264.

34 Thus to some degree Moll Flanders can be said to dramatize the 'social antagonism' that Richetti identifies as a central conflict in the scandal chronicle. See Richetti, 124. While I do not wish to suggest here that the novel's primary purpose is social critique, I do think it is worth observing that Moll is far more censorious of her upper-class victims than she is of her fellow criminals.

$35 \mathrm{MF}, 222$.

$36 \mathrm{MF}, 98$. 
It is perhaps worth observing, with reference to discussions of the novel as a cautionary tale, that many of the text's seeming moral reflections are essentially moral deflections, as Moll argues that 'It must be the Work of every sober Reader to make just Reflections on [her actions], as their own Circumstances may direct. ${ }^{37}$ These instances of deference define the process of reading Moll Flanders as one in which readers must likewise negotiate between their avowed views of the text and their hidden motives (information, titillation, entertainment) for reading it.

Of course, it is not solely on the basis of Moll's role as spy that the reader is prompted to trust her, since relying on Moll as a narrator involves endorsing the narratives she chooses to cite as well as her own eyewitness accounts. In these situations, the reader is invited to trust Moll on the basis of her ability to assess the relative reliability of the statements of others. Like a careful historian, the authorial Moll is constantly evaluating her sources, weighing the truth claims of narratives provided by other 'insiders,' as well as interrogating the statements made by potential victims or opponents. While Moll's adult judgments are not unfailingly correct - she is still duped by her Lancashire husband's mistress, for example - the novel's dramatization of her seduction as a transition from ingenuous honesty to disingenuous skepticism helps bolster the authority of the wiser, more cynical Moll who narrates the final tale.

Like many secret histories, then, Moll Flanders is delivered from the perspective of a disillusioned narrator, one who might once have been a sincere advocate of those people and events that she has subsequently determined to expose. This retrospective narration often results in a redramatization of the historical process as haphazard or impenetrable: thus, the novel's full title prepares us to expect a series of anecdotes (Moll's 'fortunes and misfortunes'), and not a coherent causal narrative. Likewise, the authorial Moll often halts the progress of her story to consider situations in which she might have acted differently, or met with different circumstances. ${ }^{38}$ The apparent randomness of many of the events of Moll's life - she avoids being seized for theft in a silver-smith's shop, for example, because 'by great good Luck [she has] an old silver Spoon in [her] Pocket' - itself poses a kind of implicit challenge to ideas

$37 \mathrm{MF}, 365$.

38 On the casuist resonances of these moments, see G. A. Starr, Defoe and Casuistry (Princeton: Princeton University Press, 1971), 111-64. 
of rational progress and individual agency. ${ }^{39}$ Finally, just as the narrator of The White-Staff begins his condemnation of the Staff's enemies by lamenting the general prevalence of political corruption, so Moll frequently extends her critique of individual agents or situations into broader complaints against 'the Wickedness of the times' or 'the growing Vice of the Age. ${ }^{40}$

Just as the wizened older Moll who narrates the final text maintains a cynical consciousness of the contingency and impenetrability of human affairs, so the younger Moll who acts in it remains ever attentive, after her initial loss of innocence at the hands of the Colchester rake, to discrepancies between thoughts, words, and deeds. Up until the point at which she decodes her seducer's deceptive behaviour, Moll occupies the position of the ingenuous general reader herself. She expresses confidence in publicly-avowed opinions, trusting the eldest son's false flattery and offers of marriage largely because she fails to separate the commonplaces he espouses from the hidden truth of his designs. While this Moll, unused to keeping secrets, lets her face betrays her feelings, her subsequent seduction and abandonment by the elder brother teaches her to scrutinize others' intentions far more carefully. From this point onwards, Moll begins to identify and manipulate the views of those around her.

It is Moll's ability to inhabit others' perspectives, in fact, that makes her such a skilful seductress and thief. Like the conspirators against Harley in The White-Staff, she is a surreptitious 'spectator,' observing her victims and entering into their feelings the better to be able to betray them. ${ }^{41}$ Thus, she is able, after her fall from innocence, to 'read' the disguised 'anguish' in the 'forc'd smiles' of her clients in the Mint in much the same way that her seducer was able to read her blushes at his compliments. ${ }^{42}$ Sometimes Moll assumes a potential victim's point of view in physiological terms - she pockets a gambler's money, for example, when she is 'sure he [can] not see it' - and sometimes in more subtly psychological ones - she can often determine the concealed motives behind other people's public actions. ${ }^{43}$ This latter consideration explains why, throughout her criminal career, Moll generates imagined

$39 \mathrm{MF}, 345$.

$40 \mathrm{MF}, 63,229$.

41 Moll's role as spectator or journalist nicely mirrors that of other secret historians, including John Oldmixon, Eliza Haywood, and Defoe.

$42 \mathrm{MF}, 109$.

$43 \mathrm{MF}, 335$. 
narratives of her victims' lives based on her encounters with them. When she steals a little girl's expensive beaded necklace, for example, Moll recounts a hidden back-story in which she assumes both the girl's mother's and her maid's points of view:

This String of Beads was worth about Twelve or Fourteen Pounds; I suppose it might have been formerly the Mother's, for it was too big for the Child's wear, but that, perhaps, the Vanity of the Mother to have her Child look Fine at the Dancing School, had made her let the Child wear it; and no doubt the Child had a Maid sent to take care of it, but she, like a careless Jade, was taken up perhaps with some Fellow that had met her by the way, and so the poor Baby wandred till it fell into my Hands. ${ }^{44}$

Moll similarly imagines that the two rings she snatches from a windowboard were 'to be sure laid there by some thoughtless Lady, that had more Money than Forecast, perhaps only till she wash'd her Hands. ${ }^{45}$ On some occasions, her entrance into a victim's point of view is so complete that she begins to feel that victim's distress at her own robbery. When she steals the valuables of a woman whose house is on fire, for example, Moll reflects:

... it really touch'd me to the very Soul, when I look'd into this Treasure, to think of the disconsolate Gentlewoman who had lost so much by the Fire besides; and who would think to be sure that she had sav'd her Plate and best things; how she wou'd be surpriz'd and afflicted when she should find that she had been deceiv'd, and should find that the Person that took her Children and her Goods, had not come, as was pretended, from the Gentlewoman in the next Street, but that the Children had been put upon her without her own knowledge. ${ }^{46}$

Conversely, Moll's few failures as a thief typically result from an inability to occupy her intended victim's point of view: thus, a gentleman's horse 'had been a Booty to those that had understood it,' but leaves the jewelry-and-lace-thieving Moll 'at a loss to know what to do'; ${ }^{47}$ foreign tourists stopping in the country are similarly 'found ... generally empty of things of value. ${ }^{48}$

$44 \mathrm{MF}, 258$.

$45 \mathrm{MF}, 260$.

$46 \mathrm{MF}, 272$.

$47 \mathrm{MF}, 326$.

$48 \mathrm{MF}, 337$. 
Moll does not always rely solely on visual cues to piece her victims' histories together: she dupes two young ladies in St. James's Park, for example, by surreptitiously gathering information from a servant, and then feigning intimacy with the family:

I saw abundance of fine Ladies in the Park, walking in the Mall, and among the rest, there was a little Miss, a young Lady of about 12 or 13 Years old, and she had a Sister, as I suppose it was, with her, that might be about Nine Year old: I observ'd the biggest had a fine gold Watch on, and a good Necklace of Pearl, and they had a Footman in Livery with them ...

When I heard her dismiss the Footman, I step'd up to him, and ask'd him, what little Lady that was? . . . and the Fool of a Fellow told me presently ... abundance of things enough for my business. ${ }^{49}$

Once in possession of enough of their story to serve her needs, Moll 'puts [her]self in a Rank with this young Lady,' physically aligning her perspective with that of her victim, and speaks 'so familiarly to her of her whole Family that she [can] not suspect but that [Moll knows] them all intimately. ${ }^{50}$

Such tactful information-gathering skills similarly assist Moll in discovering and screening potential allies. Her encounters with both the bank clerk and the 'Governess' demonstrate her talent for manipulating conversation to obtain private information from others, while keeping her own story concealed. These conversations serve as reminders that Moll's criminal career flourishes not just because she excels at uncovering others' secrets, but also because she excels at concealing her own. After her second husband's flight into France, Moll immediately removes 'quite out of [her] Knowledge, and [goes] by another Name,' thus beginning a long career of physical and psychological disguises ${ }^{51}$ Like Harley's enemies in The White-Staff, she becomes adept at secretly manipulating public opinion, using the 'female Buz' of gossip to generate false reports so universally convincing that they prompt her brotherhusband to discount a written avowal of her poverty as poetic license, and her Lancashire husband to propose marriage on the authority of 'a foolish hearsay. ${ }^{, 52}$

49 MF, 330-31.

$50 \mathrm{MF}, 331$.

$51 \mathrm{MF}, 108$.

$52 \mathrm{MF}, 241,198$ 
Moll's use of mobs to conceal her thefts enact on a physical level the same manipulations of the general point of view she often effects more subtly as rumour-monger. She describes the attempted theft of one woman, for example, 'in a Crowd, at a Meeting-House, where I was in very great Danger of being taken':

I had full hold of her Watch, but giving a great Jostle, as if some body had thrust me against her, and in the Juncture giving the Watch a fair pull, I found it would not come, so I let it go that Moment, and cried out as if I had been kill'd, that some body had Trod upon my Foot, and that there was certainly Pick-pockets there; for some body or other had given a pull at my Watch. ... I had no sooner said so, but the other Gentlewoman cried out $a$ Pick-Pocket too.... At that very instant, a little farther in the Crowd, and very Luckily too, they cried out a Pick-pocket again, and really seiz'd a young Fellow in the very Fact ... and the poor Boy was deliver'd up to the Rage of the Street. ${ }^{53}$

When, in a later episode, Moll really is apprehended by an angry mob, she acts the part of the wronged woman so convincingly that she ends up leading a crowd 'of about 500 People' to the local Justice of the Peace, all of them certain that 'a Mercer had stop'd a Gentlewoman instead of a Thief. ${ }^{54}$

Ultimately, only those narratives - and those narrators - that Moll deems equally aware of the potential discrepancy between public and private views are capable of securing her trust. Like The Secret History of the White-Staff, Moll's autobiography simultaneously undermines the 'public' account of her life, and champions the other private histories that support her assertions of honesty: thus the banker's description of himself as having 'a Wife, and no Wife' echoes Moll's claims of having a 'Husband, and no Husband', ${ }^{55}$ and Jemy's account of his twenty-five year career as a highwayman who 'has often sat in the Coffee-Houses, and heard the very People who he had robb'd give Accounts of their being robb'd' parallels Moll's pleasurable spectatorship of her victims. ${ }^{56}$ It is wholly appropriate that the conclusion of the novel should find Moll not only paired with a man whose sophisticated manipulation of point of view parallels her own, but also transported with that husband to a

$54 \mathrm{MF}, 317$.

$55 \mathrm{MF}, 187,108$.

$56 \mathrm{MF}, 384$. 
New World dedicated to questioning the values of the Old. The Virginia of Moll Flanders is a land devoid of a common past, a place in which historical precedent holds no sway and private shame may be made public glory. 'Many a Newgate Bird,' as Moll's mother observes, 'becomes a great Man. ${ }^{57}$

Near the end of the second part of The Secret History of the White-Staff, Defoe's narrator argues that 'History is design'd to relate the Actions of Men' regardless of whether 'they have done well, who some People would have nothing well said of, or ill, who others think are always in the Right. ${ }^{58}$ So, too, does Moll, happily settled in Virginia, ultimately conclude that even the most horrific of her life's secrets must find its way out: 'A Secret of Moment should always have a Confident, a bosom Friend, to whom we may Communicate the Joy of it, or the Grief of it, be it which it will, or it will be a double weight upon the Spirits, and perhaps become even insupportable in itself; and this I appeal to all human Testimony for the Truth of. ${ }^{59}$ The real burden for Moll in maintaining a secret life has not been the shame of finally confessing her private thoughts and deeds, but rather, the loneliness of concealing them. To have 'no Body to whom [she can] in confidence commit the Secret of [her] Circumstances,' Moll reflects, 'is the worst Condition, next to being in want, that a Woman can be reduc'd to. ${ }^{\prime 60}$ While the publication of her memorandums comes too late to cause Moll any personal danger, however, it also comes too late to obtain personal sympathy - and perhaps too full of crimes to obtain even a posthumous vindication. For her, as for other secret historians, the relief of public confession can only be purchased at a high price: that of sympathy for the treacherous self.

Both Moll's desire to confess and her readers' desire to read those confessions have, as I noted at the outset of this paper, helped to assure Moll Flanders a place in contemporary bookshops and present-day classrooms. The comparative exclusion of a work like The Secret History of the White-Staff from the literary 'Rise of I' is complex, and undoubtedly has to do in part with the instability of a category like point of view in narrative practice. But that exclusion also seems to be a product of generic and disciplinary biases that have led previous critics to find 'conscious artistry' in Moll Flanders's first-person pronouns and failed

$57 \mathrm{MF}, 134$.

58 WS, 2.56, mispag. as 2.55 .

$59 \mathrm{MF}, 407$.

$60 \mathrm{MF}, 181$. 
objectivity in The White-Staff's. I hope the similarities outlined in this paper have highlighted some of the ways in which point of view may be used as another means of connecting, rather than separating, different texts, perhaps linking Moll Flanders not just with secret histories, but with a range of narrative forms - diaries, journals, memoirs, biographies - that sought to explore the past primarily in first-person terms.

NOELLE GALLAGHER

University of Chicago 